\title{
ELEMENTOS BÁSICOS DA TEORIA DA INDIVIDUAÇÃo DE GiLbERT Simondon
}

\author{
Caio César Cabral ${ }^{1}$
}

\begin{abstract}
Resumo: No presente artigo, será feita uma análise geral do modo como o problema da formação do indivíduo é tratado, na teoria da individuação de Gilbert Simondon. O filósofo constata que tanto o atomismo quanto o esquema hilemórfico postulam cada qual um princípio específico que sustenta o processo de individuação: tem-se, pois, um monismo substancialista, no primeiro caso, enquanto, no segundo, um esquema dualista constituinte (matéria/forma). São justamente tais concepçóes que fazem com que essas escolas se tornem alvo das críticas mais incisivas de Simondon. Para ele, se, ao contrário, a hecceidade do indivíduo não estiver mais vinculada nem ao átomo, nem ao par hilemórfico, entâo não se terá mais a necessidade de invocar um princípio absoluto de individuação. Abrir-se-á, em vez disso, um caminho para se considerar como primordial, na investigação filosófica, a descrição da operaçáo a partir da qual o indivíduo vem a constituir-se. Assumindo, pois, tal ideia como ponto de partida, Simondon desenvolve e oferece, conforme se mostrará, uma concepção de individuação profundamente original e instigante, capaz de inspirar novas maneiras de se abordar o tema.
\end{abstract}

Palavras-chave: Indivíduo. Individuação. Informação. Transdução. Gilbert Simondon.

\section{INTRODUÇÁO}

As ideias propostas por Gilbert Simondon (1924-1989) costumam surpreender o leitor que tem contato com sua obra pela primeira vez. Chama a atenção, sobretudo, a perspectiva filosófica adotada no tratamento de uma das questôes mais importantes da história do pensamento ocidental: a natureza do indivíduo. A perspectiva do autor é essencialmente relacional ou dinâmica

\footnotetext{
${ }^{1}$ Doutor pelo Programa de Pós-Graduação em Filosofia do Departamento de Filosofia da Universidade de São Paulo (USP), São Paulo, SP - Brasil. (D) https://orcid.org/0000-0002-8324-2501. E-mail: caiock@gmail.com.
}

https://doi.org/10.1590/0101-3173.2021.v44n2.05.p63

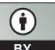

This is an open-access article distributed under the terms of the Creative Commons Attribution License. 
e, nela, a formação do indivíduo - tanto a do indivíduo físico quanto a do biológico - consiste em um processo de interação que envolve não somente $o$ ser individual como o mundo, ou o meio, no qual este ser se acha inserido. Em outros termos, o aspecto positivo da filosofia de nosso autor não tem ligação com qualquer representação passiva do mundo, ou com qualquer concepção substancialista do indivíduo, pronta a considerá-lo como consistindo em sua própria unidade, e, portanto, como algo fundado sobre si mesmo.

Simondon ocupa-se, antes, com a ideia de um indivíduo que se encontra em uma relação ativa e permanente com o mundo; relação que, segundo o autor, é o que fundamenta e define o processo mesmo de individuação. Tal processo, por sua vez, é apresentado como sendo o único caminho viável para que se possa obter uma adequada compreensão das características essenciais de todo indivíduo. O ponto de partida de uma abordagem filosófica eficaz do indivíduo significará, portanto, a descrição da ontogênese mesma em todos os seus traços, evitando-se o postulado de um princípio absoluto que fundamentaria, ou orientaria, o processo de individuaçáo.

Exporemos, neste artigo, as razóes pelas quais Simondon, ao discutir a problemática da individuação, submete à crítica os conceitos filosóficos tradicionais de forma, matéria, átomo e substância, e elege como prioritários os de "realidade pré-individual", "devir", "equilíbrio metaestável”, "energia potencial”, "relação", "informação" e, principalmente, o de "transdução". Observaremos, mais exatamente, o modo como Simondon elimina, por meio dos conceitos elencados, a necessidade de se procurar um princípio absoluto para a individuação. Em vez de um princípio dessa natureza, nosso autor opta por privilegiar, em sua abordagem filosófica, a própria operação a partir da qual o indivíduo vem a formar-se ou constituir-se. ${ }^{3}$

\footnotetext{
${ }^{2}$ Devido à nossa preocupação em manter o máximo de fidelidade à tese de Simondon sobre a individuaçấo, consideramos imperioso dar atenção desde já à traduçấo que propomos dos termoschave destacados no texto. Eis os termos originais em francês, extraídos de $L$ 'individuation à la lumière des notions de forme et d'information (2005): devenir (devir); réalité préindividuelle (realidade préindividual); equilibre métastable (equilíbrio metaestável); énergie potentielle (energia potencial); relation (relação); information (informação); transduction (transduçáo) (SIMONDON, 2005).

${ }^{3}$ Cabe esclarecer que o exame por nós proposto será, tendo-se em conta os limites deste artigo, de natureza geral e tomará como objeto os modos físico e biológico de individuação, ambos apresentados nas duas primeiras partes de $A$ individuação à luz das noçôes de forma e de informação, obra de Simondon que ora tomamos como norte (respectivamente, na parte I, intitulada "A individuação física", e na parte II, que tem como título "A individuação dos seres viventes").
} 


\section{Os CONCEITOS FUNDAMENTAIS DA TEORIA DA INDIVIDUAÇÁO}

Ao tratar do conceito filosófico de "indivíduo" ou de "ser individual", em $A$ individuação à luz das noçôes de forma e de informação (2005), Gilbert Simondon depara-se, antes de tudo, com a desvalorização, na história do pensamento, das noçóes de processo, de relação e de devir. ${ }^{4} \mathrm{Na}$ visão do autor, essas noçóes, em verdade, se revelam essenciais para o tratamento da questão da natureza do indivíduo e, nesse sentido, a teoria da individuação de Simondon entra em cena como uma tentativa importante de superação do referido problema. A desvalorização da noção de relação é, segundo o filósofo, efeito de concepçôes baseadas em duas formas de pensamento que partem, de um lado, da afirmação da supremacia do par "forma-matéria" e, de outro, de uma valorização de seres em si mesmos já individuados, tudo em detrimento do processo que engendra os indivíduos - o processo de individuação. No hilemorfismo, segundo a leitura que dele faz Simondon (1995, p. 22),

[...] o princípio de individuação não é [...] captado na individuação mesma enquanto operação, senão naquilo de que tem necessidade esta operação para poder existir, a saber, uma matéria e uma forma: supóe-se o princípio contido seja na matéria, seja na forma.

Por seu turno, o atomismo substancialista antigo admite como pressuposto "[...] partículas elementares que existem desde toda a eternidade e que são os verdadeiros indivíduos; o princípio de individuação, no atomismo, é a existência mesma da infinidade dos átomos." (SIMONDON, 1995, p. 22). De acordo com a interpretação de Simondon, os atomistas consideram o átomo um ser substancial, ilimitado e inalterável, ou seja, que não se corrompe ao longo das combinaçóes de que participa, sendo, portanto, simples. Os atomistas também pensam que a relação entre os átomos é tornada possível graças ao vazio, dando-se, além disso, ao azar, fato este que evidencia a precariedade das condiçóes constitutivas dessa relação. Assim, os compostos resultantes vêm a existir somente por acidente, ou seja, pelo número infinito de encontros ocorridos entre os átomos, no decorrer do tempo (SIMONDON, 1995, p. 140). Simondon constata, com isso, que ambas as escolas de pensamento (hilemorfismo e atomismo) partilham de uma lógica substancialista, segundo a qual tanto a forma, quando considerada

\footnotetext{
${ }^{4}$ Convém notar que, no que diz respeito à parte do trabalho de Simondon que trata especificamente dos aspectos físico e biológico da individuação, a estruturação das argumentações do filósofo é a mesma em L'individu et sa gênese physico-biologique (1964) e em L'individuation à la lumière des notions de forme et d'information (2005); em verdade, os textos são quase idênticos, em ambas as obras.
} 
transcendente em relação à matéria, quanto os átomos indivisíveis e imanentes terminam por produzir "[...] uma zona obscura que recobre a operação de individuação.” (SIMONDON, 1995, p. 25).

Recusando as formulações acima, por considerá-las insuficientes para dar conta de uma concepçáo dinâmica dos seres, Simondon desenvolve, então, uma visão do princípio de individuação em que o objetivo é "[...] conhecer o indivíduo através da individuação, em vez de a individuação a partir do indivíduo." (SIMONDON, 1995, p. 26). Nosso autor, mais exatamente, propóe que não se conceba o indivíduo como princípio, mas sim "[...] como uma realidade relativa” (SIMONDON, 1995, p. 26); como possuidor de uma essência entendida como um estado ou fase do ser, a qual consiste em relaçóes que compóem ou formam o indivíduo, e antes da qual existe apenas o que o autor chama de "realidade pré-individual" (SIMONDON, 1995, p. 26, grifo nosso). O indivíduo é aquilo que surge como uma fase desse ser préindividual, antes da qual "[...] não existia nem como indivíduo, nem como princípio de individuação.” (SIMONDON, 1995, p. 26).

As fases às quais alude nosso filósofo devem aqui ser compreendidas como resoluções (ou estruturas) provisórias, parciais, relativas, uma vez que a individuação, por compreender sucessivas incompatibilidades, é sempre rica em potenciais. $\mathrm{O}$ indivíduo, por conseguinte, não é um ser em si completo; não é "o todo do ser", mas sim um momento do ser, o efeito de uma individuação resolutória (SIMONDON, 1995, p. 86). Marin e Lima (2009) acrescentam que a tese de Simondon segundo a qual a individuação contém seu próprio princípio, transformando e atualizando singularidades, interdita

[...] desde o início a ideia de [...] um princípio que prefigure as características do indivíduo a ser constituído. Encontramo-nos, ao ler seus textos (de Simondon), diante de um mundo em tensão permanente, mundo detentor de singularidades, composto de estrutura e energia, de variaçôes: mundo intempestivo, mal dito por um princípio de unidade ou de identidade onde nenhuma transformação parece mais possível (MARIN; LIMA, 2009, p. 275).

Assim, o indivíduo pensado por nosso filósofo, longe de ser tomado como princípio de individuação, é um ser em transformação, nunca terminado ou concluído, já que a individuação prossegue permanentemente.

Ainda conforme a concepçáo filosófica de Simondon, existem a princípio forças compondo o ser pré-individual, constituindo todo processo 
de individuação uma singularidade que se manifesta enquanto sistema, no interior do qual essas forças entram em relação de tensão (SIMONDON, 2009, p. 26). Margairaz (2013, p. 4) entende que Simondon, por meio de tais pressupostos,

[...] dá ao pré-individual o estatuto de possibilidade real, e não simplesmente lógica, de gênese dos indivíduos, descrevendo-o como [...] suscetível de desfasar-se, ou seja, de engendrar a partir de suas próprias tensōes um par de realidades complementares que são o indivíduo e seu meio.

Esse sistema, que compreende indivíduo e meio, mostra-se, com isso, rico em energia potencial, e é sobretudo desse estado energético, ou tenso, que depende o processo de individuação. Explica Simondon (2009, p. 85) que "[...] a noção de sistema é necessária para definir a condição energética, pois só há energia potencial em relação com as transformações possíveis em um sistema definido." Nesse ponto, percebemos claramente que Simondon, ao expor sua filosofia da ontogênese, acolhe explicaçôes e constataçóes da ciência contemporânea (particularmente as da física de seu tempo) para construir sua teoria, o que nos leva, outra vez, a aceitar a interpretação de Margairaz. A comentadora, ampliando nossa compreensão da noção de préindividual, salienta que tal noção, ao ser extraída por Simondon dos estados em desequilíbrio da termodinâmica, designa também

[...] a situação energética particular de um sistema no qual a repartição desigual de energia entre as moléculas constitui uma forma de energia potencial que pode levar a transformaçóes estruturais em caso de modificação do estado energético do sistema (MARGAIRAZ, 2013, p. 9).

Ocorre, então, no seio do ser pré-individual e com a formação do sistema tenso, um processo de devir, o qual Simondon (2009, p. 26) entende como sendo "[...] uma capacidade que tem o ser de desfasar-se em relação a si mesmo." "Notemos, nesse ponto, que as expressóes "ser individual" e "totalidade pré-individual”, recorrentes na exposição de Simondon, nos permitem afirmar que sua teoria, em vez de apresentar uma concepção do "ser enquanto ser", isto é, do ser absoluto, puro e sempre igual a si próprio, oferece, antes, uma compreensão segundo a qual a essência do real se constitui como

\footnotetext{
5 Optamos por traduzir como "desfasar-se" a expressão em francês "se déphaser". Eis o trecho que extraímos do texto original de Simondon: "[...] une capacite que l'être a de se déphaser par rapport à lui-même.” (SIMONDON, 1995, p. 23).
} 
totalidade permanentemente metaestável. Ora, tal totalidade pré-individual indica que o "ser" de que fala Simondon é, antes de tudo, inconciliável consigo mesmo. Assim, na concepção filosófica do autor, o devir, que aqui é sinônimo de aparição de fases do ser (ou seja, o desfasar-se próprio do ser), deixa de ser considerado como aquilo que se opóe ao ser - tradicionalmente, a natureza deste é concebida como perfeita e fixa, enquanto a do devir é entendida como imperfeita, porque cambiante, e por isso carente da imutabilidade característica do verdadeiro ser. Para Simondon (2009, p. 26), é possível, antes, adotar uma visão contrária e conceber o devir "como uma dimensão do ser".

Chabot (2003) explica o pré-individual de Simondon, explorando a noção de meio amorfo em estado de "caos". Trata-se, ressalta ele, de um meio amorfo concebido como um caos auto-organizante, uma vez que "[...] é impossível falar do caos sem referência a algum tipo de ordem. $\mathrm{O}$ adjetivo 'amorfo', que tem a marca de uma ausência, define o meio em termos de sua carência de forma." (CHABOT, 2003, p. 85). Logo, em vez de definir o caos amorfo em termos meramente negativos, em vez de seguir a perspectiva segundo a qual uma tal expressão não possui em si mesma nenhuma positividade lógica, Simondon, ao conceber o pré-individual, o faz tendo em mente um caos auto-organizante, que em sua própria natureza aguarda uma individuação, bastando, para que esta ocorra, que as condiçôes energéticas necessárias sejam cumpridas (CHABOT, 2003, p. 86).

Chabot (2003, p. 86) segue adiante, elucidando que,

[...] em termos aristotélicos, o pré-individual seria potência sem ato - uma pura passividade. Mas Simondon rejeita esta terminologia. Aristóteles dá primazia ao ato e define a potência em termos daquilo que falta para o ato. Tal concepção de potência é elaborada, do ponto de vista lógico, como falta (isto é, em termos de negaçáo).

Mas Simondon faz questão de desviar-se da lógica tradicional: para ele, o pré-individual é profundamente positivo, pois é potência geradora e criativa ou, se quisermos dar lugar às palavras de Chabot (2003, p. 86),

[...] sua potência é uma vitalidade ainda não domesticada, uma pura natureza, uma physis, uma natura naturans. O pré-individual é natureza apreendida em sua fonte, natureza ainda intocada pela determinação, sem forma e ilimitada, mas já plena de uma vitalidade que obterá forma por meio da determinaçáo. 
Virno (2004), também discutindo as variaçôes sobre o tema do préindividual, cita uma passagem de Simondon, a qual revela algo acerca do que nosso próprio filósofo tem em mente, quando utiliza o termo:

Poder-se-ia chamar natureza a esta realidade pré-individual que o indivíduo leva consigo, tratando de encontrar na palavra natureza o significado que lhe davam os filósofos pré-socráticos: os físicos jônicos encontravam aí a origem de todas as espécies de ser, anterior à individuação: a natureza é realidade do possível que, sob as espécies do apeiron de que fala Anaximandro, faz surgir toda forma individuada; a Natureza não é o contrário do homem, mas a primeira fase do ser, sendo a segunda a oposiçáo entre o indivíduo e o entorno (milieu) (SIMONDON apud VIRNO, 2004, p. 30).

É Simondon mesmo, por conseguinte, quem situa historicamente a noção de pré-individual com a qual pensa a realidade que antecede toda individuação: tal noção, ou tal realidade, equivale ao "ilimitado" ("apeiron") de que falava Anaximandro. Margairaz (2013, p. 5) explica que o que interessa a Simondon, na filosofia pré-socrática jônica, "[...] é a concepção de um elemento primeiro, infinito, ilimitado, suscetível de operar uma separação a partir de si mesmo para engendrar seres distintos [...]"

Chabot informa ainda sobre um ponto de vista interessante de Simondon, a respeito dos filósofos pré-socráticos: estes, com seu sentido de Natureza, teriam sido "[...] os verdadeiros pensadores da individuação." (CHABOT, 2003, p. 86). Chabot nota que Simondon apreciava esses filósofos pelo fato de a ideia que tinham acerca da realidade náo ter sido impactada pela fascinação com o ser já individuado, fascinação esta que dominaria os filósofos atomistas, sobretudo Epicuro, a ponto de levá-los a conceber a totalidade do real como a soma de todas as coisas já individuadas. Os pré-socráticos anteriores aos atomistas não se apoiaram sobre um princípio de individuação, "[...] um primeiro termo a partir do qual os indivíduos se desenvolvem [...]. Eles tiveram a intuição de um verbo (crescer) e de um meio ainda não-formado, 'sem fase', mas em si mesmo vivo." (CHABOT, 2003, p. 86). O próprio Simondon teria afirmado, sobre os pré-socráticos, que, "[...] para eles, a presente realidade do mundo é entendida por sua gênese, sendo a cosmogonia tangível e concreta, como a progressiva mudança de estado sofrida pela argila, ao absorver mais água pelas mãos do oleiro." (SIMONDON apud CHABOT, 2003, p. 87). 


\section{DEVIR, EQUiLíbrio METAESTÁVEL E RELAÇÃo}

Percebemos em Simondon, portanto, uma teoria filosófica que privilegia o conceito de devir, e náo o conceito de puro ser, entendendo-se o devir não só como o próprio desfasar-se do ser, como ainda aquilo de que depende o processo de individuaçáo: "[...] o ser no seio do qual se consuma uma individuação é aquele no qual aparece uma [...] repartição do ser em fases, que é o devir." (SIMONDON, 2009, p. 27). A partir disso, o ser pré-individual está permanentemente desfasando-se, visto que os potenciais inerentes à realidade pré-individual nunca são esgotados (SIMONDON, 2009, p. 26). Nesse quadro, o pré-individual engendra, através do devir, o par indivíduo/meio, o qual Simondon concebe como indispensável para a resolução das tensốes igualmente oriundas do pré-individual, e ao mesmo tempo para "[...] uma conservação destas tensôes." (SIMONDON, 2009, p. 27) .

$\mathrm{O}$ autor concebe, em decorrência, a individualidade como sendo essencialmente um "sistema tenso, sobressaturado", no seio do qual se dá o processo mesmo de individuação (SIMONDON, 2009, p. 27). A sobressaturação, estado que Simondon aponta como verificável exclusivamente no nível da individuação física (notadamente na gênese dos cristais), produz as várias singularidades ou fases do ser, sendo as noçôes de "unidade" e de "identidade" - advindas da lógica clássica - aplicáveis unicamente, conforme o filósofo, a essas fases que se produzem, ou seja, aos resultados da operação de individuação, e ainda assim de maneira parcial. Tais noçóes nunca podem ser aplicadas à realidade pré-individual em si, uma vez que Simondon a supóe, por encontrar-se ela em estado metaestável, incapaz de apresentar uma "identidade durável" ou uma "unidade captável". ${ }^{7}$ Ela, em vez disso, encontra-se em um estado primitivo rico em potenciais (podendo manifestar-se, do ponto de vista físico, ora como onda, ora como corpúsculo, quando o assunto é a natureza

\footnotetext{
${ }^{6}$ No estágio da individuação física, já é possível identificar como constituintes desse par, por exemplo, o cristal (enquanto indivíduo) e a matéria ou substância amorfa presente no entorno; de tal matéria o sistema individuante constantemente se apropria, estruturando-a ou organizando-a (SIMONDON, 2009).

7 É outra vez Margairaz (2013) quem nos explica ser esta, com efeito, “[...] uma hipótese crítica, cuja função consiste em referir-se a um aspecto da realidade que não podemos conceber senáo de forma negativa, como uma dimensão do real não individuada que, como tal, escapa à percepção tanto quanto à unidade e identidade dos conceito.s" (2013, p. 2). O pré-individual tem, entretanto, um aspecto positivo, podendo dar lugar "[...] a uma individuação, mas ainda se mantendo após esta operação enquanto potencial restante, permitindo, assim, à realidade individuada continuar sua individuação." (MARGAIRAZ, 2013: 2).
} 
da luz), indícios estes de uma "metaestabilidade primitiva e original" desta totalidade pré-individual (SIMONDON, 2009, p. 29).

O equilíbrio metaestável é, com efeito, outra noção importante a ser empregada, para que a individuação possa ser pensada adequadamente, porque, de acordo com Simondon, só se conhecia, até então, "[...] uma única forma de equilíbrio: o equilíbrio estável.” (SIMONDON, 2009, p. 28). Mas essa primeira concepção perde de vista o processo do devir, já que o equilíbrio estável

[...] corresponde ao mais baixo nível de energia potencial possível; é o equilíbrio que se alcança em um sistema quando todas as transformaçóes possíveis foram realizadas e já não existe nenhuma força; todos os potenciais foram atualizados e o sistema, tendo alcançado seu nível energético mais baixo, não pode transformar-se de novo (SIMONDON, 2009, p. 28).

Simondon afirma ser o equilíbrio metaestável radicalmente diferente do estado de repouso característico do equilíbrio estável, pelo fato de este não poder intervir de nenhum modo na busca do princípio de individuação. Tal princípio somente pode ser apreendido, em todas as suas modalidades, como “[...] um caso de resolução de um sistema metaestável.” (SIMONDON, 2009, p. 28). Para Simondon, a concepção de equilíbrio metaestável “[...] deve muito ao desenvolvimento das ciências", tendo como base sobretudo a noção de "[...] energia potencial de um sistema" (SIMONDON, 2009, p. 28), ${ }^{8}$ Ele toma como ponto de partida a ideia de energia potencial presente em um sistema físico para construir o conceito de metaestabilidade: tal energia se manifesta com nitidez, quando

[...] se supóe, por exemplo, que um corpo aquecido de maneira homogênea - e que não possui, portanto, nenhuma energia térmica potencial, já que apenas ele constitui um sistema - possa servir para fazer surgir uma energia potencial quando se o coloca em presença de outro corpo de temperatura diferente (SIMONDON, 2009, p. 92).

\footnotetext{
${ }^{8} \mathrm{O}$ caso paradigmático de estruturação a partir de um estado metaestável é, na visão de Simondon, o da cristalização. Reproduziremos aqui o modo sucinto com que Margairaz (2013) nos explica a natureza de tal modificação energética: "[...] para que um cristal sólido se forme a partir de uma solução líquida, é preciso que esta última se encontre numa situação energética de sobrefusão, ou seja, um estado de equilíbrio relativamente estável, mas que não corresponde ao estado de estabilidade obtido por um sistema em que todas as transformaçōes possíveis ocorreram, e que está no seu nível mais baixo de energia potencial. Em seguida, basta um contato mínimo, um simples contato com um germe cristalino, para que surja do encontro entre a solução e esta pequena quantidade de matéria vinda de fora uma malha cristalina de estrutura geométrica." (MARGAIRAZ, 2013, p. 9).
} 
Nesse caso, a energia potencial advém por meio de uma relação de heterogeneidade em um sistema; ou seja, os dois corpos, com temperaturas diferentes, sofrem transformaçôes, ao serem postos em contato. Assim, "[...] a capacidade de uma energia para se tornar potencial está estreitamente ligada à presença de uma relação de heterogeneidade, de dissimetria em relação a outro suporte energético." (SIMONDON, 2009, p. 92). Simondon (2009, p. 93) entende que, no caso de qualquer objeto individual,

[...] o fato de formar parte de um sistema define a possibilidade de açóes mútuas em relação com os demais objetos que constituem o sistema, o que faz com que o fato de pertencer a um sistema seja definido por uma reciprocidade virtual de açôes entre os termos do sistema.

A esta altura, parece-nos já ser possível apreender a relevância conferida por nosso autor à ideia de relaçâo: "[...] a individuação necessita de uma verdadeira relação, que só pode existir em um estado de sistema que encerra um potencial." (SIMONDON, 2009, p. 93). Na visão de Simondon, a relação, em verdade, é mais do que uma necessidade da individuaçáo, possuindo o estatuto de ser e, assim, constituindo uma dimensão da individuação: a relação com o mundo “[...] é uma dimensão da individuação, na qual participa o indivíduo a partir da realidade pré-individual que se individua etapa por etapa." (SIMONDON, 2009 , p. 34). A relação aqui não é algo apenas pensado; não se trata de uma relação simplesmente conceitual entre dois termos extremos, como a forma, de um lado, e a matéria, de outro. De acordo com Simondon, (2009, p. 37),

[...] a relaçáo é uma modalidade do ser [...]. Uma relação deve ser captada como relação no ser, relaçáo do ser, maneira de ser, e não simples relação entre dois termos, aos quais poderíamos conhecer adequadamente mediante conceitos, já que teriam uma efetiva existência separada.

Quer isto dizer que o próprio indivíduo não é caracterizado por Simondon como sendo apenas termo de uma relação; ele é, "[...] pelo contrário, teatro e agente de uma relação; [...] é teatro ou agente de uma comunicação interativa." (SIMONDON, 2009, p. 84). Para nosso autor, "[...] o indivíduo, propriamente falando, não está em relaçáo nem consigo mesmo, nem com as demais realidades; é o ser $d a$ relação, e não ser $e m$ relação, pois a relação é operação intensa, centro ativo." (SIMONDON, 2009, p. 84). Por isso, o princípio de todo indivíduo "[...] é o indivíduo mesmo em sua atividade, que é relacional em si mesma.” (SIMONDON, 2209, p. 84). 


\section{INFORMAÇÁO, ALAGMÁTICA E TRANSDUÇÃo}

Como vimos, a atividade relacional implica a metaestabilidade, traço característico de todo regime que encerra potencialidades; contudo, tratase aqui de um regime ou sistema tenso que o indivíduo - especialmente o indivíduo vivo - mantém permanentemente. Mais que isso, o indivíduo impulsiona esse regime, pois sempre transporta consigo "[...] uma certa carga associada de realidade pré-individual, animada por todos os potenciais que a caracterizam.” (SIMONDON, 2009, p. 32). ${ }^{9}$ Devido a essa carga, outras individuaçôes são possíveis, já que essa natureza pré-individual ligada ao indivíduo é considerada fonte segura de estados metaestáveis posteriores. ${ }^{10}$ Nesse contexto, a forma é pensada não como aquilo que age ou que vem do exterior, influenciando a operação de individuação, mas, antes, como significando o processo mesmo de informação. A informação, não tendo ligação com uma forma fixa ou previamente dada, também não é definida por nosso autor em seu sentido tradicional de simples transmissão tecnológica de mensagem - informação como aquilo que circula entre emissor e receptor.

Ora, o estado metaestável do ser pré-individual, em meio ao qual se dá o que Simondon chama de uma "informação primeira", é anterior à dualidade emissor/receptor e, por conseguinte, a qualquer mensagem a ser transmitida (SIMONDON, 2009, p. 36). A informação significa, então, a operação de uma tomada de forma que surge quando uma operação de individuação se encontra em situação na qual dois níveis díspares de realidade podem tornarse sistema: "[...] a informação é, portanto, um início de individuação, uma exigência de individuação, nunca é algo prévio.” (SIMONDON, 2009, p. 36, grifo nosso). Ela só ocorre devido à tensáo de um sistema, sendo inerente somente a uma problemática; há, pois, um problema a ser solucionado através da comunicação, mediada pelo indivíduo, entre ordens distintas de magnitude

9 Combes (2013) explica que "[...] um sistema físico é dito estar em equilíbrio metaestável (falso equilíbrio) quando o mínimo de modificação dos parâmetros do sistema (pressão, temperatura, etc.) é suficiente para quebrar o equilíbrio do sistema." (COMBES, 2013, p. 3). Ainda no nível físico, mais precisamente sobre o estado energético do ser pré-individual, o qual antecede todo processo de individuação, acrescenta o comentador que, “[...] antes de cada individuação, o ser pode ser entendido como um sistema que contém energia potencial. Ainda que exista em ato no interior do sistema, esta energia é dita potencial porque ela necessita, para se estruturar, ou seja, para se atualizar segundo certas estruturas, de uma transformaçáo do sistema." (COMBES, 2013, p. 3).

${ }^{10}$ Margairaz (2013) entende que a ideia segundo a qual o pré-individual constitui uma carga da natureza, ou do apeirón, que o indivíduo leva consigo, não deve ser interpretada num sentido em que o pré-individual constitui um peso ou fardo para o indivíduo, mas no sentido de ser ele "[...] semelhante a uma carga elétrica, uma reserva de energia potencial disponível para novas transformaçóes [...]" (MARGAIRAZ, 2013, p. 7). 
(dessa maneira é que surge, por exemplo, o cristal enquanto indivíduo mediador das ordens micro e macrofísica).

Sem admitir, portanto, a presença de qualquer elemento pressuposto (como a forma prévia) a conduzir a solução ou operação de informação, Simondon entende que "[...] a informação é aquilo pelo que a incompatibilidade do sistema não resolvido se torna dimensão organizadora na resolução." (SIMONDON, 2009, p. 36). E mais: “[...] a informação é a fórmula da individuação, fórmula que não pode preexistir a essa individuação; pode-se dizer que a informação é sempre presente, atual, pois é o sentido segundo o qual um sistema se individua." (SIMONDON, 2009, p. 36).

Chabot (2003) nos fornece esclarecimentos adicionais acerca da importância que o conceito de informação tem, para Simondon. Explica primeiramente que esse conceito se estende para além da filosofia da tecnologia, aplicando-se também à física, à biologia e outros campos, e acrescenta que a informação pode ser compreendida em três sentidos principais: sintático, semântico e pragmático. Vejamos cada um deles:

[...] o primeiro sentido concerne aos problemas de transmissão de informação. Sua aplicação inicial é estritamente técnica. As questôes de sintaxe dizem respeito a como a informação é codificada, aos canais de transmissão, às capacidades físicas dos sistemas de informação [...]. A informação também pode ser abordada por um ângulo semântico. Em tal caso, a questáo primária concerne ao significado dos símbolos que constituem a mensagem. Uma questão importante para a semântica é identificar as convençóes comuns que devem ser compartilhadas pelo transmissor e pelo receptor de um sinal de modo que o sentido da informação transmitida possa ser mutuamente compreendido. Finalmente, a informação presta-se a uma análise pragmática: como isso afeta as condutas do transmissor e do receptor? (CHABOT, 2003, p. 80).

Ora, Chabot destaca que é esse terceiro sentido que importa para a teoria da individuação de Simondon, uma vez que o estudo pragmático sobre a informaçáo pode ser comparado com a investigação escolástica das formas. Essa comparação evidencia uma diferença importante entre as duas abordagens. Enquanto, no período escolástico, o assunto primário é descobrir o efeito da forma sobre a matéria, na teoria da informação, tal questão é reformulada da seguinte maneira: qual o efeito da informação sobre o meio no qual ela ocorre? Prossegue Chabot (2003, p. 80): “[...] insatisfeito com a concepção lógica da forma, Simondon revisitou a questão medieval da individuação com a noção 
de informação em mãos." O comentador se refere, como se nota facilmente, à recepção escolástica do hilemorfismo aristotélico e, sem citar nomes de filósofos ou fazer qualquer referência a obras desse período, declara que

[...] alguns escolásticos consideravam que todas as formas eram estáticas. Aqueles que acreditavam em uma forma única, rígida, sustentavam que a sua única função era seu efeito determinante sobre a matéria. Tal função é diametralmente oposta ao dinamismo: seus adeptos recusam aceitar que uma forma possa ser ativa em si própria, independentemente de seu papel na especificação das propriedades das coisas individuais. Simondon foi a favor da interpretação oposta. Em sua teoria, a forma e a ação estão combinadas em uma única noção: informaçáo (CHABOT, 2003, p. 80).

O que torna a interpretação de Simondon diferenciada é a proposição de acordo com a qual a informação é uma operação. Não se tem mais a velha determinação, em sentido aristotélico; o sentido principal desse conceito passa a ser, pois, o de mutação. Chabot também se refere à informação como o "gatilho da mudança"; frisa que ela "[...] se torna o fator que póe em movimento o processo de individuação." (CHABOT, 2003, p. 80). Ou seja, o comentador não deixa de reforçar a ideia, que destacamos há pouco, de que a informação é o início da individuação.

A informação, supondo tensão e início de estruturação de um sistema, remete-nos a outro elemento importante da teoria da individuação de Simondon, para o qual já sinalizamos mais atrás: a alagmática (allagmatique, no original em francês). O termo "alagmática" refere-se à teoria de Simondon acerca da operação (ou do processo genético), a qual “[...] é, na ordem das ciências, simétrica à teoria das estruturas, constituída por uma uniáo sistemática de conhecimentos particulares: astronomia, química, biologia.” (SIMONDON, 1995, p. 261). ${ }^{11}$ Nosso autor explica que, se se considera

[...] uma estrutura como sendo o resultado de uma construçáo, pode-se dizer que a operação faz aparecer a estrutura tanto quanto a modifica. A operação é o complemento ontológico da estrutura e vice-versa. $\mathrm{O}$ ato contém tanto a operaçáo como a estrutura. Assim, a atenção, segundo o lado do ato no qual ela se prende, retém o elemento operaçáo ou o

11 Quanto à origem do termo alagmática, informa-nos Domingues (2013), em entrevista concedida à revista IHU On-Line, que esse nome se origina do grego allatein (modificar e trocar), tendo o significado de teoria geral das trocas e das mudanças de estados, ou ainda de ciência das operaçóes. Disponível em: http://www.ihuonline.unisinos.br/index.php?option=com_ content $\&$ view=article\&id=5243\&secao=430. Acesso em: 20 jul. 2016. 
elemento estrutura, deixando de lado seu complemento (SIMONDON, 1995, p. 261).

Simondon (1995, p. 262) apresenta o exemplo da atividade de um geômetra, cujo foco pode deslocar-se, enquanto executa seu ato, da estrutura para a operação:

[...] se o geômetra traça uma paralela a uma linha reta, ele presta atenção apenas ao elemento estrutural que interessa ao pensamento geométrico, qual seja, o fato de que uma reta é traçada, e com uma tal relação a uma outra reta. A estrutura do ato é o paralelismo de uma reta em relaçáo a uma outra reta. Mas o geômetra poderia prestar atenção ao aspecto operacional de seu ato, ou seja, ao gesto pelo qual ele traça, sem se preocupar com o que está traçando. $\mathrm{O}$ gesto de traçar possui seu esquematismo próprio. $\mathrm{O}$ sistema é operatório, não estrutural. $\mathrm{O}$ gesto procede de uma volição, a qual é um gesto mental. Ela supóe a disponibilidade de certa energia que é liberada e comandada pelo gesto mental através de todos os elos de uma cadeia de causalidades.

A alagmática, para Simondon, significa, portanto, uma preocupação com o aspecto operatório de um ato, de uma mudança, e mesmo de uma dada ciência. Mas, mais que uma preocupação, para Simondon, a alagmática é a possibilidade de se realizar efetivamente uma teoria da operação: sua própria teoria da individuação é, antes de tudo, uma teoria sobre a operação de individuação.

Guchet (2005) nos dá uma boa elucidação do aspecto crítico da alagmática, afirmando que Simondon busca, através dela, evitar a cisão entre o sujeito e o objeto, cujo legado é a perda de todo dinamismo operatório (GUCHET, 2005, p. 191). Entretanto, como ocorre tal perda? Simondon entende que os filósofos, ao lidarem com a questáo específica do conhecimento, costumam dar mais importância à estrutura que à operação, ao estático em vez de ao dinâmico, ao ser em vez de ao devir. Nesse cenário, a crítica mais incisiva de Simondon, mostra-nos Guchet, recai sobre Kant. Para o filósofo alemão, a operação cognitiva não é parte integrante do objeto, mas do sujeito; é somente quando concebida como dispositivo pertencente ao sujeito que a operação pode conduzir ao conhecimento objetivo.

Todavia, ocorre que a ciência, fundada sobre o sujeito, tem acesso aos fenômenos e mesmo à objetividade das estruturas, sem, no entanto, 
conhecer o próprio sujeito e seu dinamismo espontâneo. Com efeito, o sujeito transcendental não pode ser conhecido, mas apenas postulado, o que faz com que qualquer reflexão sobre as operações do sujeito não possa ser considerada como conhecimento objetivo. Diz-nos, então, Guchet que, para Simondon, se o sujeito, enquanto postulado transcendental, não pode ser conhecido, então sua própria ontogênese é questão que fica de fora do processo cognitivo (GUCHET, 2005, p. 191-2). Cristaliza-se, assim, um hábito filosófico que acaba acarretando o desprezo pela operação, atitude que Simondon, como já sabemos, busca evitar desde o início, em sua teoria da individuação.

Fortemente ligado à alagmática, encontramos ainda outro importante conceito na teoria de Simondon, possuidor de "[...] uma multiplicidade de aspectos e de domínios de aplicação: o de transduçâo." (SIMONDON, 2009, p. 38). Destaquemos a definição que o autor nos dá do conceito:

Entendemos por transdução uma operação física, biológica, mental, social, pela qual uma atividade se propaga progressivamente no interior de um domínio, fundando-se tal propagação sobre certa estruturação do domínio operada aqui e ali: cada região de estrutura constituída serve de princípio de constituição da região seguinte, de modo que uma modificação se estende progressivamente, ao mesmo tempo em que a operaçáo estruturante (SIMONDON, 2009, p. 38).

A transdução, portanto, é o processo de individuação em progresso, sendo o caso mais elementar o do cristal, em cujo crescimento vemos as capas moleculares acumularem-se, formando "uma estrutura reticular amplificante" graças à presença do germe cristalino, um dos sustentáculos da operação (SIMONDON, 2009, p. 38). Contudo, no nível puramente físico, a transdução efetua-se apenas como estruturação repetida, ou ainda como repetição progressiva, ao contrário do que ocorre no domínio biológico, em que vemos a individuação avançar de modo constantemente variável e náo repetitivo. Com isso, Simondon acrescenta que a transdução pode ser compreendida como "[...] uma operação vital, expressando em particular o sentido da individuação orgânica.” (SIMONDON, 2009, p. 39). No nível biológico, o ser vivo individua-se, ao resolver problemas ou superar tensóes, e isso ocorre por estar ele em comunicação ativa com o meio. Essa relação com o ambiente é capaz de tornar o indivíduo sujeito a modificaçóes em sua estrutura interna. 
Porém, a principal responsável por tais mudanças é, conforme Simondon, uma atividade que parte de um centro do ser vivo, ou seja, de sua interioridade, a qual Simondon vincula a uma problemática interna própria do vivente, e que, graças sobretudo ao estado de equilíbrio metaestável, se estende em diversas direçôes. A metaestabilidade existe, logo, no próprio indivíduo enquanto sistema e não apenas no sistema "[...] que o indivíduo forma com seu meio.” (SIMONDON, 2009, p. 31). O indivíduo biológico torna-se, nesse contexto, capaz de intervir ele próprio como um elemento dos problemas de ordem vital a serem resolvidos, já que ele mesmo é chamado por Simondon de "[...] sistema individuante e sistema individuando-se." (SIMONDON, 2009, p. 31). Assim, para Simondon, e em se tratando principalmente da individuação biológica, "[...] a transdução é aparição [...] de estruturas em um ser em estado de tensão pré-individual” (SIMONDON, 2209, p. 39); ou seja, é atividade estruturante inerente a um ser em permanente estado de incompatibilidade, cuja natureza não pode, por isso, ser apreendida enquanto unidade e identidade em sentido tradicional.

A transdução é uma atualização constante de potenciais que guardam forte relação com a incompatibilidade primeira, qual seja, a do ser préindividual ainda sem fases - o que significa que a transdução é concebida como o prosseguimento da informação. Nosso autor admite primeiramente a existência de uma incompatibilidade ontogenética primordial, ou seja, uma tensão entre forças que antecede qualquer processo de individuação. Para Simondon, essa condição primeira "[...] é o que há de mais positivo no estado do ser pré-individual, a saber, a existência de potenciais." (SIMONDON, 2009, p. 40). Ora, se a individuação, resultante dessa condição primeira, implica não a eliminação, mas a permanência de tensóes desta natureza, então cada superação de tensão, enquanto efeito da operação transdutiva, é resultado sempre temporário no processo total de individuação. Assim, nosso filósofo assume que a individuação, enquanto ocorre, não é mais que o "[...] desfasar-se do ser a partir do seu centro pré-individual de incompatibilidade potencializada." (SIMONDON, 2009, p. 40). ${ }^{12}$

Encontramos em Mackenzie (2003) uma percepção penetrante da natureza abarcadora do conceito de transdução: “[...] o conceito de transdução é uma via para teorizar e figurar as coisas em termos de relacionalidade, como processos de recontextualização e em termos de generatividade. Como conceito, permite pensar acerca da metaestabilidade ou da abertura dos contextos aos acontecimentos. Também designa um estilo de pensamento que envolve 
Em suma, podemos compreender que a informação é uma operação transdutiva de tomada de forma, operação que caracteriza todo processo de individuação. Esse processo, por seu turno, possibilita a emergência dos indivíduos a partir de um "fundo" pré-individual e por meio de uma defasagem do ser (ou deste fundo) em indivíduo e meio.

\section{CONSIDERAÇÓES FINAIS}

Pressupor a existência prévia de um princípio de individuação, como o átomo ou o composto matéria/forma, significa desprezar qualquer vínculo essencial do indivíduo com o processo mesmo de individuação; nos casos do atomismo e do hilemorfismo aristotélico, significa postular o indivíduo como algo já dado e sem qualquer relação com a operação pela qual ele se constitui enquanto indivíduo. A subversão que Simondon promove, ao investigar a individuação, consiste em recusar o indivíduo já constituído ou o ente individuado como ponto de partida para a explicação desse processo. Simondon deseja, mais exatamente, “[...] conhecer o indivíduo através da individuação, em vez de a individuação a partir do indivíduo” (SIMONDON, 2009, p. 26); isso leva o filósofo a conceber o indivíduo como uma realidade relativa, como possuidor de uma essência entendida como uma fase do ser, na qual se dão relaçóes tensas que compóem o indivíduo.

Na visão do filósofo, toda individuação significa o advento de uma fase do ser pré-individual, o que identifica ou ao menos relaciona a individuação com a noção de devir e não com a de puro ser. $\mathrm{O}$ indivíduo não é, assim, considerado como idêntico ao ser, pois o ser é mais rico, mais durável e mais amplo que o indivíduo: o indivíduo não é constituinte primeiro e elementar do ser, porém, um modo de ser ou, ainda, um momento do ser.

Graças a esse ser mais amplo, o indivíduo constituído sempre é palco de outras individuaçóes, posto que a individuação nunca esgota os potenciais desse ser pré-individual, o qual está sempre presente: “[...] o primeiro estado pré-individual do ser pode continuar existindo, associado ao resultado de uma primeira individuação.” (SIMONDON, 2009, p. 485).

O estado primordial de unidade tensa do ser pré-individual é o que possibilita o aparecimento das fases do ser. O ser pré-individual, pleno de

acompanhar e participar da ontogênese ou individuação das coisas num dado domínio." (MACKENZIE, 2003, p. 9). 
potencial energético, é anterior a toda aparição de fases; dele é que depende todo processo de individuação. Indispensável é notar que não se trata de um ser em estado estável, coerente consigo mesmo, mas de um ser em estado metaestável. O ser a que alude Simondon não é uno e imutável, não se reduz à noção de Parmênides, para quem "o ser simplesmente é"; em vez disso, o ser é capaz de expansão a partir de si mesmo, pois sempre se encontra potencializado, existindo como ser e também como energia. A individuação depende, antes de qualquer outra coisa, de uma defasagem dessa realidade prévia, quando dois níveis díspares de realidade abrem caminho para a tomada de forma de um indivíduo.

CABRAL, C. C. Basic elements of Gilbert Simondon's theory of individuation. Trans/form/ ação, Marília, v. 44, n. 2, p. 59-82, Abr./Jun, 2021.

\begin{abstract}
In this paper, we will do a general analysis of how the problem of individual formation is treated in the theory of the individuation of Gilbert Simondon. The philosopher notes that both atomism as hilemorphic scheme postulate a specific principle that supports the individuation process: there is a substantialist monism in the first case, and in the second, a constituent dualistic scheme (matter/form). It is precisely such conceptions that make these schools the target of the most incisive criticism of Simondon. For him, if, on the contrary, the essence of the individual is not bound to the atom nor to the hilemorphic pair, then there is no longer the need to invoke an absolute principle of individuation. Instead, a path is opened to consider, in philosophical inquiry, the description of the operation from which the individual comes to be constituted. Assuming this idea as a starting point, Simondon develops and offers, as we will show, a deeply original and instigating conception of individuation, capable to inspire new ways to approach the theme.
\end{abstract}

Keywords: Individual. Individuation. Information. Transduction. Gilbert Simondon.

\title{
REFERÊNCIAS
}

CHABOT. P. The Philosophy of Simondon: Between Technology and Individuation. New York: Bloomsbury, 2003.

\section{COMBES, M. Gilbert Simondon and the Philosophy of the Transindividual.}

Cambridge: The Mit Press, 2013.

DOMINGUES, I. A tecnologia na ótica de Simondon. 2013. Disponível em: http:// www.ihuonline.unisinos.br/index.php?option=com_content\&view=article\&id=5243\&sec ao $=430$. Acesso em: 20 jul. 2016. 
GUCHET, X. Simondon, La cybernétique et lês sciences humaines: genèse de l'ontologie simondonienne dans deux manuscrits sur le cybernétique. Chiasmi International. Memphis: University of Memphis, n. 7, 2005, p. 187-206.

MACKENZIE, A. Transduction: invention, innovation and collective life. 2003. Disponível em: http://www.lancs.ac.uk/staff/mackenza/papers/transduction.pdf. Acesso em: 20 jul. 2014.

MARGAIRAZ, S. Entre apeíron présocratique et métastabilité thermodynamique: l'idée de préindividuel chez Gilbert Simondon. 2013. Disponível em: http://methodos. revues.org/3191. Acesso em: 10 jul. 2014.

MARIN, A.; LIMA, A. Individuação, percepção, ambiente: Merleau-Ponty e Gilbert Simondon. Educaçáo em revista, v. 25, n. 03, 2009, p. 265-281.

SIMONDON, G. L'individu et sa genèse physico-biologique. Grenoble: Jérôme Millon, 1995.

SIMONDON, G. L'individuation à la lumière des notions de forme et d'information. Grenoble: Millon, 2005.

SIMONDON, G. La individuación a la luz de las nociones de forma y de información. Buenos Aires: Cactus y La Cebra, 2009.

VIRNO, P. Multidão e princípio de individuação. Lugar Comum - Estudos de Mídia, Cultura e Democracia. Rio de Janeiro: LABTeC / UFRJ, n. 19, 2004, p. 27-40.

Recebido: 18/2/2019

Aceito: 23/2/2020 
CABRAL, C. C. 